\title{
EFL Students' Perceptions and Attitudes toward Using Communicative Activities in CLT Classroom
}

OPEN ACCESS

Volume: 9

Special Issue: 2

Month: September

Year: 2021

E-ISSN: 2582-1334

Received: 11.07.2021

Accepted: 27.08.2021

Published: 15.09.2021

Citation:

Rezalou, Ali, and

Oktay Yağiz. "EFL

Students' Perceptions and

Attitudes toward Using

Communicative Activities

in CLT Classroom."

Shanlax International

Journal of Education,

vol. 9, no. S2, 2021,

pp. 112-24.

DOI:

https://doi.org/10.34293/

education.v9iS2-Sep.4376

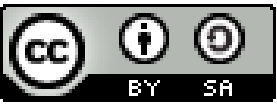

This work is licensed under a Creative Commons Attribution-ShareAlike 4.0 International License

\author{
Ali Rezalou \\ Atatürk University, Turkey \\ https://orcid.org/0000-0002-0402-9156
}

\author{
Oktay Yağiz \\ Atatürk University, Turkey \\ https://orcid.org/0000-0001-7076-7774
}

\begin{abstract}
In this study, the effects of using the communicative activities in communicative language teaching (CLT) classroom to improve students' speaking performance and reduce their difficulties in speaking skill were investigated. Classroom action research (CAR) was considered as the research design. A quantitative method was followed in this study. The researcher intended to improve the students' speaking ability by using the Communicative Language Teaching Method, communicative activities. The teaching and learning process was divided into ten cycles and was carried out in ten weeks. Each cycle consisted of four interconnected stages: Planning, Action, Observation, and Reflection. Overall, students favored activities that provided a competitive classroom environment and led to a high level of classroom participation. The findings revealed the effectiveness of speaking classes because students were significantly more satisfied with their speaking ability after the interventions. Statistically significant differences were found in students' perceptions and attitudes toward using communicative activities.

Keywords: Action research, Communicative Language Teaching (CLT), Communicative activities.
\end{abstract}

\section{Introduction}

Many language learners in the world study English with aim of developing proficiency in speaking. Understanding the nature and ability of the second language (SL) or foreign language (FL) speaking is a highly difficult task. People use speaking for different goals and each goal requires different speaking skills. For example, basic conversations are used for making friends or for social contact with other people, or just engaging in a friendly chat with close friends. On the other hand, engaging in discussion with someone, our purpose may be expressing opinions, persuading individuals, or clarifying the words or sentences. There are some situations that speaking is used for describing some things, complaining, making requests, entertaining people with anecdotes, and giving instructions. Every one of these purposes to do speaking involves good knowledge about spoken language that reflects context or situation, the specific roles of participants, their relationships. The role of speaking in foreign language teaching and learning is important because by talking, people share their ideas and thoughts. English teachers probably face situations where students become reluctant to speak. It can be said that factors such as lack of trust, lack of words, or some uninterested conversation topics are the source of this problem. Comparing to the other language teaching methods in the world that have tried to improve teaching and learning quality and to provide the 
desired effect on the language learners, communicative language teaching has been successful in an effective way. According to many teachers, communicative language teaching (CLT) can be one of the best methods to help students in everyday life and communication to practice the language in classrooms. Various methods provide active use of language in English language teaching and can improve speaking skills. However, Communicative Language Teaching is a frequently used method in other countries and is successful in teaching speaking skills. In the study, the researcher has examined the effect of the CLT method on students' speaking skills; students who took speaking lessons by the teacher-researcher have been taught by this method for 10 weeks. During the lessons, the verbal interaction strategies, performances, and difficulties of the students have been observed and measured. In addition, positive or negative effects of using communicative language teaching methods in language classes have been revealed. By adopting CLT "teachers may provide opportunities to learners to develop both accuracy and fluency in a CLT environment" (Farooq, 2015, p. 118). According to Brown (2007, p. 226), the focus of CLT classrooms is on "speaking and listening skills, on writing for specific communicative purposes, and on authentic reading texts."Teaching English in Turkey has been affected by changes and innovations in language teaching. Therefore, policymakers emphasized the necessity of developing students' communicative skills as an important objective of ELT in Turkey (Turkish Education Board, 2006). In this situation, EFL teachers can have an important role in the process of decision-making in the language classroom (Lamie, 2005).Communicative goals of policymakers are not addressed in the Turkish context and the classrooms; the English language is taught and presented structurally (Alagözlü, 2012; Işık, 2011; Uztosun, 2013a). Students spend many years learning English in a structured-based teaching atmosphere but they have difficulty in improving verbal communication or oral skills (Alagözlü, 2012, p. 1759). Because of over dependence on structure-based language teaching in primary, secondary, and high schools, students have difficulty in communicative skills and then they enroll in different departments of the university for completing their English education without adequate attention to speaking or writing in English. On the other hand, students in ELT departments have a chance for improving their English but they take intensive English classes emphasizing skills in the first two years. Therefore, providing useful classes at this level is critically important. By reviewing the discussed reasons, for providing skill-based English courses effectively at ELT departments at universities, considering and supporting students' anticipated needs in detail is essential. These mentioned issues are the main causes of conducting this study. Generally, the researcher attempted to find and represent solutions and guidelines for developing and promoting effective oral interaction and speaking classes for language learners in ELT departments. The researcher followed an approach focusing on learners' needs and then wanted to conduct appropriate interventions for improving oral interaction practice in classrooms. To attain this goal, students' voices for making a decision to do classroom practice were considered carefully, and then the researcher for implementing desired lesson plans in speaking classrooms conducted the methodology of action research (AR). As the last word, the findings of this research may be useful to see the impact of action research in the EFL context through using the CLT method, listening to students' voices, and considering their implications for developing and improving EFL learners' participation, performance, and oral proficiency in the classroom.

Recent studies have indicated that EFL learners and even non-native English teachers as EFL teachers encounter several difficulties during the learning and teaching process. Within the EFL context, it has been observed that many language learners spent long years learning English but they still have struggling to be fluent speakers in English. In the current study, the effects of using CLT method for improving students' performance, oral interaction, verbal communication strategies, and reducing their difficulties in speaking skills were investigated. To meet this aim of the research, the researcher prepared required lesson plans, questionnaires, activities, Preand post-speaking Tests, and other materials.In this 
sense, in the current study, the researcher tried to answer the following questions:

1. What are the students' perceptions toward using communicative activities in the CLT classroom?

2. What are the students' attitudes toward using communicative activities in the CLT classroom?

\section{Literature Review}

To describe the concept of attitude, the scholars have offered many important and useful definitions. According to Oskamp (1977, p. 19), attitude is responding positively or negatively to a particular object or item. In Oskamp's (1977) definition of attitude, three components of attitude can be seen. First, a cognitive component is related to a person's ideas and beliefs toward the object. The affective component deals with the person's feelings and emotions about the object. The last one is a behavioral component that is a person acts towards the object. "Attitude toward a language is someone's mental attitude or feelings towards the position of their language or other's languages" (Amin, 2020, p. 29).Gardner (1985) emphasizes the importance of attitude in language learning because students' success or failure in language learning is related to it. If the learners have favorable attitudes towards language learning, they will experience satisfaction in the learning process. Positive attitudes lead to improved language proficiency. Conversely, negative attitudes affect students' perceptions unfavorably. In addition, the teacher and the methodology influence learners' attitudes in the classroom. Experienced language teachers that are interested in students' needs can increase their students' positive attitudes through using attractive teaching methodology. As discussed above, attitudes can affect students' success and failure in their learning process. Students' satisfaction with activities, classroom atmosphere, and methodology of teaching can encourage their attitudes towards the target language learning positively. In the present study, learners' feelings about using communicative activities and their satisfaction were measured.

Brignall (2001) states that through the perception process people can attach meaning to the world. In other words, people through perception try to comprehend the world. In the perception, process people try to understand something through particular things. Brignall (2001) categorizes the perception process in three stages as follows:

In the first stage that is the selection stage, stimuli attended are selected through the five senses: sight, sound, smell, taste, and touch. In the second stage or the organization stage, individuals psychically organize the stimuli or information for understanding the stimuli. The last stage is the interpretation stage, the meaning is provided by individuals to the stimuli. In this stage, the interpretation is done based on the individuals' needs, beliefs, values, experiences, self-concept, and expectations. Hence, perception means individuals' beliefs and opinions toward events, situations, and things. They attach meanings to the environment through their interpretations of their experiences, expectation, interests, and attitudes. From the above-mentioned points, it can be concluded that learners' expectations, interests, and experiences in learning the class environment and teaching methodologycan affect their opinions toward learning a new language. Having positive perceptions toward language learning leads the students to successful learning.

\section{Previous Studies}

The researchers have used communicative activities and CLT method in the EFL context effectively at various levels of education. Over the past twenty years, many research projects have investigated the effects of communicative activities in language learning. A few important case studies are described below. Phuphanpet (2004) used varieties of communicative activities including information gap activities, role plays, jigsaws, and mapped dialogues to investigate the first-year certificate students' development in speaking English. The participants were 20 students at Samutprakan Technical College in Thailand. In this study, the researcher used different instruments such as lesson plans, speaking tests, selfevaluation, and observation forms. The results of the study showed that there was a significant difference in the learners' speaking in English after practicing communicative activities. In Wongsuriya's (2003) study, the first-year diploma vocational students' English communicative competence in speaking and listening skills at Rajamangala Institute in Thailand 
through real-life situations were investigated. A simple random sampling technique was used to select seven first-year vocational students. Communicative activities, pre-and post-test, a teacher-rating form to measure students' communicative competence, students' attitude questionnaire, and an audiorecorder were the instruments of the study. After analyzing the results of the study, significant differences were found in students' communicative competence in speaking and listening skills before and after the study. A high mean score $(M=4.50)$ was found in the students' attitudes toward learning English. Kethongkum (2005) studied the effect ofrole-playing and information gap activities as English supplementary materials to develop the third-year certificate vocational students' listening and speaking competence in the Tourism and Hotel major in Thailand. Eighteen third-year certificate vocational students participated in this study. The researcher used a students' pleasure questionnaire, lesson plans, supplementary materials, and a pre-and post-test and as instruments of the study. The analysis of the results revealed a significant difference in the students' listening and speaking competence after the study. Therefore, students' attitudes toward using information gap and role-play activities were positive. At a Malaysian college,during the transition period from secondary school to college,students' attitudes toward learning English were studied by Troudi and Choy (2006). Participantswere 100 first-year students. Their majors were business and computer science. The weekly journals and student interviews were the instruments of the study. After analyzing the results of the study, a change was found in the students' attitudes after entering the college and they had positive attitudes toward learning English when they studied at the college. Also, students' self-confidence was improved while speaking because the environment encouraged them to use English communicatively.

\section{Method}

Based on the research objectives and conducting in the classroom, Classroom Action Research (CAR) was considered as the research design by the researcher. "Classroom Action Research is highly needed in improving teaching and learning both for students and teachers" (Wulandari et al., 2019, p. 318 ). It aimed to identify the problematic situation to look into deeply and systematically (Burns, 2010a).The researcher intended to find the feasible problems related to EFL learners' speaking skills and implement some actions for improving their speaking ability through using the Communicative Language Teaching Method, communicative activities. Therefore, at first, the researcher collected concerning data with the obstacles and weaknesses of the teaching and learning process related to learners' oral communication ability and then identified research problems. After that, he planned, implemented some actions, and then evaluated and reflected them systematically. A quantitative method was followed in this study.

\section{Participants}

The teacher-researcher of the study was a Ph.D. student in the ELT Department of English Language Teaching at Ataturk University. Students as participants in this study were 40 EFL second-year students that were enrolled in a four-year ELT teacher education program to become EFL teachers in the future. The age element was not included in the design of items about the participants' demographic information. Convenience sampling, as one of the non-probability or non-random sampling techniques, was used to select participants.

\section{Data Collection Instruments \\ Lesson Plans}

The researcher considered the following procedures in constructing lesson plans:

1. Studying the objectives of the study, description of the course, goals of the study, learners' competency, and then designing the lesson plans according to principles of communicative activities

2. Selecting the functions and contents relevant to the objectives of the study from textbooks

3. Designing lesson plans based on the research method, principles of communicative language teaching, and providing students with different communicative activities

4. Checking and discussing lesson plans to provide feedback 
5. Examining the lesson plans practically in a pilot study with 40 students

6. Revising, modifying, and making essential changes concerning the weak points of interventions for improving after doing the pilot study

Ten lesson plans including different types of communicative activities were used in this study.

\section{English Speaking Test}

To test speaking ability, there are different ways like interviews, information gap techniques, cloze tests, semi-direct tests, picture tests, role-plays, band descriptors, and technology but among mentioned types of speaking tests, interviewing is the most widely used. Interviewing is a communicative process. In this process, the teacher asks students open-ended questions and expects the students to answer the questions in the target language. In the process of interviewing, students find opportunities for expressing their opinions and answering questions. During an interview, teachers do assessing the use of language properly or not properly by students (Goh \& Aryadous, 2010). Comparing to the other assessment types, interviews are better to evaluate students' speaking performance on specific topics. Additionally, the results of interviews are a good source for revising or enhancing instruction and curriculum. Teachers or assessors can record the students' speaking performance to evaluate later. Also, they can evaluate their students' performance immediately during the interview. Therefore, in this study, the Pre-test and Post-test were designed in the form of interviews and were administered and conducted to the students to understand the condition of the students' ability in speaking skill before and after implementing action research. The main objective of the tests is to see any significant improvement in the students' speaking ability. To evaluate students' speaking ability, the researcher constructed the pre-test and post-test as follows:

1. After studying the course description, the researcher decided to review some useful books for constructing a speaking test.

2. Two experienced ELT experts examined the testand then checked the content validity of the test. After that, the researcher applied the test to second-year EFL students.

3. The researcher considered the experts' comments to improve the weak points in revising the test.

\section{The Rubric of Speaking Ability}

The rubrics of speaking are useful tools that contain the students' scores in speaking performance. The needed scores of the study were obtained through speaking pre-test and post-test. At the end of the semester, scores of two tests were compared. The results indicated the usefulness or not usefulness of the communicative activities for improving students' speaking skills. The researcher used Hui's (2011) analytic rubric of the speaking ability for this study.

\section{Observation Checklist}

An observation checklist was used to gain data through the observation in the process of teaching and learning speaking in the CLT classroom.

\section{Questionnaire}

To elicit the second-year EFL students' perceptions toward using communicative activities, the researcher used a perception questionnaire in the CLT classroom. Phisutthangkoon (2012) developed this questionnaire. The ELT experts confirmed the validity of the questionnaire. During the pilot study, the Cronbach Alpha( $\alpha$ ) Coefficient of the questionnaire was calculated. It was $r=0.75$. This questionnaire consists of twelve Likert -scale items. All items were rated by students using the five-point scale ranging from very low (1) to very high (5). To gain information about the second-year EFL students' attitudes toward the communicative activities, the researcher used an attitude questionnaire. It consists of 10 Likert-scale items with a five-point rating scale from very low to very high. Phisutthangkoon (2012) developed this questionnaire and the researcher used it in the current study. After confirming the validity of the questionnaire by the thesis advisor and ELT experts, it was piloted to the $40 \mathrm{EFL}$ students and its Cronbach Alpha $(\alpha)$ Coefficient was calculated which was $r=0.76$. The students rated all items from very low to very high. As a result, all students shared anything freely concerning the speaking classroom and helped me for gathering rich data about needed interventions and term evaluation. 
Data Collection Process in the Pilot and Main Study

To control the usefulness of the research design, the researcher experienced similar procedures before the main study. Conducting the pilot study is an important part of research studies. Predicting the outcomes of data collection is not possible. Therefore, the results of the pilot study allow the researcher for revising the weakness of the data collection process. The pilot study lasted for two weeks. During the pilot study, the researcher did not observe any harm, detriment, and unreasonable stress caused by the research process. On the contrary, the students' reaction was positive to carry out the activities. The data collection process in the main study lasted eight weeks and this took place in the 2018-2019 academic year, the fall semester. Finally, the researcher employed the post-test for students.

\section{Research Procedure}

The process of the research was divided into ten cycles and each cycle consisted of two sessions and was carried out in ten weeks. There were four interconnected stages: Planning (P), Action (A), Observation $(\mathrm{O})$, and Reflection $(\mathrm{R})$ in each cycle. Lewin designs the classroom action research as a series of four stages: planning, action, observation, and reflection (act. Kunandar, 2010, p. 42).

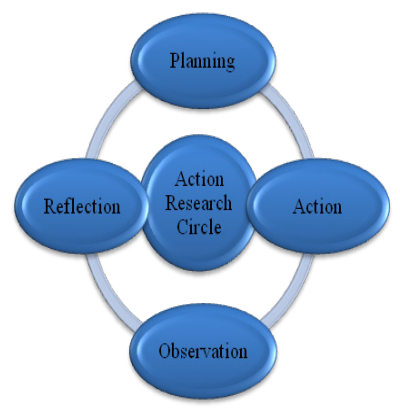

\section{Figure 1: The Action Research Cycle}

As cited in Burns (2010a), Kemmis and McTaggart (1990) proposed the procedure of action research. The researcher used this procedure in the current study that is as follows:

\section{Planning}

For doing the classroom action research successfully, the researcher paid attention to the instructional planning for all sessions and weeks. In the planning stage, the researcher planed as follows:

- The pre-test for understanding the students' previous speaking ability and post-test to compare with the pretest to know and see any improvement in the students' current speaking skill after treatment;

- The initial and final interviews to know students' previous teaching and learning process and knowing any improvement after treatment;

- The communicative lesson plans and teaching materials about the identified problems;

- The student's perception and attitude questionnaires to administer after treatment;

- Observation checklist to observe students' behavior during the teaching and learning process in the classroom.

\section{- Action}

In this stage, the researcher did what he intended to do in the classroom and managed the class. Three parts include pre-activities, whilst-activities, and post-activities were used in conducting interventions and activities in the classrooms.

\section{- Observation}

In this study, the researcher did two actions: a) teaching b) observing. During the teaching and learning process, classroom observation was done systematically. The researcher obtained useful information from the actions for recognizing the effects of the interventions (Monitoring the implementation).

\section{- Reflection}

In this stage, the researcher put in the observation checklists all information obtained through observations and then analyzed them to understand the strength and weaknesses of the new applied interventions during the teaching-learning process and repeated the cyclic process until a sufficient understanding of the problem. After reviewing the reflections, the researcher could make essential decisions for continuing or stopping the teaching and learning process (Reflection and Revision).

\section{The Researcher's Role}

The researcher as an English teacher, controller, organizer, assessor, participant, resource, and 
observer applied the Communicative Language Teaching Method and communicative activities to the EFL students in the speaking classroom.

\section{Data Analysis}

To understand and check the distribution of the quantitative data in this study, the researcher used the Shapiro-Wilk test for two questionnaires. The results of the Shapiro-Wilk test indicated that the distribution of the quantitative data is not normal. Therefore, non-parametric tests were used to analyze the quantitative data. The Wilcoxon signed-rank test is a nonparametric test. The scores of both the pretest and post-test on speaking skills were converted into the mean scores and standard deviations. Descriptive statistics and Wilcoxon signed-ranked tests were used to calculate mean scores and standard deviations of the pre-test and post-test scores and to find any significant differences between two tests and students' speaking ability before and after the study. For analyzing observations, as proposed by Patton (1980), the researcher considered the chronology of describing classroom procedures. Descriptive statistics were used to calculate the mean scores of the perception and attitude questionnaire. The researcher analyzed students' scores from the perception and attitude questionnaire and then interpreted them in this way:

$$
\begin{aligned}
& (4.21-5.00)=\text { very high } \\
& (3.41-4.20)=\text { high } \\
& (2.61-3.40)=\text { moderate } \\
& (1.81-2.60)=\text { low } \\
& (1.00-1.80)=\text { very low }
\end{aligned}
$$

\section{Reliability and Validity}

The main concern of any researcher is to conduct the research study with high quality because the quality of any research reflects the well-designed researcher procedures to find appropriate answers to research questions. Generally,validity and reliability are important issues in quantitative studies since these studies concern the generalizability of the findings. The validity of the instruments was confirmed by the ELT experts, and the reliability of the instruments was obtained through a reliability test that was the high value of alpha Cronbach $(\alpha)$ for perception questionnaire with value $(r=0.75)$ and for attitude questionnairewith value $(r=0.76)$. Also, to obtain inter-rater reliability among three raters for pretest and post-test, Intraclass Correlation Coefficient (ICC) test was conducted. "Inter-rater reliability is the extent to which two or more raters (or observers, coders, examiners) agree" (Anastasi \& Urbina, 1997). According to the results of the test, a high average measures value of intraclass correlation was found for pre-test (0.86) and post-test (0.92). Therefore, a high value of average measures (an index for the reliability of different raters averaged together) indicated that there was inter-rater reliability among the three raters.

\section{Results}

\section{The Difference between Pre-test and Post-test Scores}

Three raters assessed the speaking pre-test and post-test scores. To calculate the mean scores of the pre-test and post-test, the researcher used descriptive statistics to measure the second-year EFL students' speaking skill, and then calculated and compared the average mean score of three raters' mean scores of two tests. According to table 1, the three raters' average mean scores of the post-test were higher than that of the pre-test. The participants had a significantly average mean score on the post-test $(M=84)$ higher than the pre-test $(M=74.58)$. The results are indicated in Table 1 as follows:

Table 1: A Comparison of the Pre-Test and PostTest Mean Scores for Speaking Skill

\begin{tabular}{|c|c|c|}
\hline Raters & Pre-Test & Post-Test \\
\hline Rater 1 & 75.87 & 84.75 \\
\hline Rater 2 & 73.50 & 83.25 \\
\hline Rater 3 & 74.37 & 84 \\
\hline Average & 74.58 & 84 \\
\hline
\end{tabular}

According to Table 1, the three raters' mean scores of the post-test were much higher than those of the pre-test. The students had significantly mean scores on the post-test $(\mathrm{M}=84)$ higher than the pre-test $(\mathrm{M}$ $=74.58)$. The results indicated an improvement in the second-year EFL students' speaking skill.

The researcher used Wilcoxon signed-rank test to find the effectiveness of the communicative activities on the improvement of students' speaking 
skill. Therefore, used three Wilcoxon signed-rank tests separately for each rater's pre and post-test scores. After analyzing the Wilcoxon signed-rank tests, statistically, a significant difference was found between the two tests. The results of three Wilcoxon signed-rank test are indicated respectively in Tables 2,3 , and 4 as follows:

Table 2: Comparison of the Speaking Pre-test and Post-test (Rater 1)

\begin{tabular}{|c|c|c|c|c|c|c|}
\hline & $\mathbf{R}$ & n & M.R. & S.R & $\mathbf{z}$ & p \\
\hline \multirow{4}{*}{ Pre \& Post-Test } & Negative ranks & 0 & .00 & .00 & \multirow{4}{*}{-5.52} & \multirow{4}{*}{.000} \\
\hline & Positive ranks & 36 & 18.50 & 666 & & \\
\hline & Ties & 4 & & & & \\
\hline & Total & 40 & & & & \\
\hline
\end{tabular}

As indicated in Table 2, the results show a score on the English-speaking post-test $(\mathrm{Md}=85)$ significant difference between the pre-test and posttest of the second-year EFL students' speaking ability, $(\mathrm{z}=-5.52$, sig $=0.00, \mathrm{p}<0.05)$. The median was higher than the median score on the pre-test $(\mathrm{Md}=75)$.

Table 3: Comparison of the Speaking Pre-test and Post-test (Rater 2)

\begin{tabular}{|c|c|c|c|c|c|c|}
\hline & $\mathbf{R}$ & $\mathbf{n}$ & M.R. & S.R & $\mathbf{z}$ & p \\
\hline \multirow{4}{*}{ Pre \& Post-Test } & Negative ranks & 0 & .00 & .00 & \multirow{4}{*}{-5.59} & \multirow{4}{*}{.000} \\
\hline & Positive ranks & 38 & 19.50 & 741 & & \\
\hline & Ties & 2 & & & & \\
\hline & Total & 40 & & & & \\
\hline
\end{tabular}

As shown in Table 3, the results show a significant difference between the scores of two speaking pretest and post-test of the second-year EFL students'

speaking ability $(\mathrm{z}=-5.59$, sig $=0.00, \mathrm{p}<0.05)$. The median score on English speaking in the post-test $(\mathrm{Md}=85)$ was higher than the pre-test $(\mathrm{Md}=75)$.

Table 4: Comparison of the Speaking Pre-test and Post-test (Rater 3)

\begin{tabular}{|c|l|c|c|c|c|c|}
\hline & \multicolumn{1}{|c|}{$\mathbf{R}$} & $\mathbf{n}$ & M.R. & S.R & z & p \\
\hline \multirow{4}{*}{ Pre \& Post-Test } & Negative ranks & 1 & 4.00 & 4.00 & -5.57 & .000 \\
\cline { 2 - 8 } & Positive ranks & 38 & 20.42 & 776 & & \\
\cline { 2 - 8 } & Ties & 1 & & & & \\
\cline { 2 - 8 } & Total & 40 & & & & \\
\hline
\end{tabular}

The results indicated in Table 4 , show a significant difference between the pre-test and post-test of the second-year EFL students' speaking ability, $(\mathrm{z}=$ -5.57 , sig $=0.00, \mathrm{p}<0.05)$. The median score on the English speaking test on the post-test $(\mathrm{Md}=85)$ was higher than the pre-test $(\mathrm{Md}=75)$. It can be seen that the median scores of pre-test and post-test in three Wilcoxon signed-rank tests are the same and the median score of post-test is higher than the median score of the pre-test. According to the results of three Wilcoxon signed-rank tests and three raters' assessments, we can see a significant difference in EFL students' speaking ability between the speaking pre-test and post-test.

\section{Students' Perceptions toward Using Communicative} Activities

To explore students' perceptions toward using communicative activities at the end of the study, students were asked to answer the questions. They ratedall items on a five-rating scale from very low (1) to very high (5). Descriptive statistics were used to analyze participants' self-rating scores from the perception questionnaires. The researcher interpreted the results. The results indicated that students' perception toward using communicative activities was positive and they rated it at a very high level $(\mathrm{M}=4.31)$. The results are shown in Table 5: 
Table 5: Students' Perceptions toward Using Communicative Activities

\begin{tabular}{|l|c|c|c|}
\hline \multicolumn{1}{|c|}{ Questionnaire items } & Mean & SD & Level \\
\hline $\begin{array}{l}\text { 1. Learning through communicative activities provides a relaxed } \\
\text { atmosphere and you are happy to learn English. }\end{array}$ & 4.30 & .60 & Very high \\
\hline $\begin{array}{l}\text { 2. Learning through communicative activities help you to improve } \\
\text { your speaking ability. }\end{array}$ & 4.42 & .59 & Very high \\
\hline $\begin{array}{l}\text { 3. Learning through communicative activities increase your self- } \\
\text { confidence in speaking English. }\end{array}$ & 4.52 & .64 & Very high \\
\hline $\begin{array}{l}\text { 4. You understand the procedure of doing the communicative } \\
\text { activities clearly. }\end{array}$ & 4.22 & .53 & Very high \\
\hline $\begin{array}{l}\text { 5. The communicative activities encourage learners' classroom } \\
\text { participation. }\end{array}$ & 4.22 & .83 & Very high \\
\hline $\begin{array}{l}\text { 6. Learning through communicative activities promote a good } \\
\text { relationship among learners as well as between learners and the } \\
\text { teacher. }\end{array}$ & 4.22 & .83 & Very high \\
\hline $\begin{array}{l}\text { 7. Learning through communicative activities activates learner's } \\
\text { needs and interests. }\end{array}$ & 4.22 & .61 & Very high \\
\hline $\begin{array}{l}\text { 8. You realize that English is important after learning through } \\
\text { communicative activities. }\end{array}$ & 4.22 & .80 & Very high \\
\hline $\begin{array}{l}\text { 9. Learning through communicative activities encourage you to } \\
\text { think and increase your self-confidence. }\end{array}$ & 4.27 & .75 & Very high \\
\hline $\begin{array}{l}\text { 10. Learning through communicative activities helps you to learn } \\
\text { English naturally. }\end{array}$ & 4.30 & .68 & Very high \\
\hline 11. You like to learn English using communicative activities. & 4.37 & .62 & Very high \\
\hline $\begin{array}{l}\text { 12. You can apply the knowledge in the classroom to use in your } \\
\text { daily life after learning through communicative activities. }\end{array}$ & 4.45 & .71 & Very high \\
\hline
\end{tabular}

As indicated in Table 5, students' overall mean scores were very high with the mean score (4.31). The results were acceptable and students' perceptions toward using activities were positive. The highest perception was seen in item $3(\mathrm{M}=4.52)$. Students confirmed the improvement of their self-confidence in speaking skill through doing communicative activities. The second highest perception was item $12(\mathrm{M}=4.45)$. Students responded that they could apply their knowledge in speaking class to improve their speaking ability for using in their daily life. However, a low level of positive perception was found in items $4(\mathrm{M}=4.22)$, item $5(\mathrm{M}=4.22)$, item 6 $(\mathrm{M}=4.22)$, item $7(\mathrm{M}=4.22)$ and item $8(\mathrm{M}=4.22)$.

\section{Students' Attitudes toward Using Communicative Activities}

To understand the students' attitudes toward using communicative activities in the classroom, the students were asked to answer the attitude questionnaire and then rate all items like the perception questionnaireat five levels. Descriptive statistics were used for analyzing students' selfratings scores. After analyzing the scores, the researcher interpreted them. The results revealed students' positive attitudes toward these activities at a very high level $(M=4.47)$. The results are indicated in Table 6:

Table 6: Students' Attitudes toward Using Communicative Activities

\begin{tabular}{|l|c|c|c|}
\hline \multicolumn{1}{|c|}{ Questionnaire Items } & Mean & SD & Level \\
\hline 1. The communicative activities are interesting. & 4.32 & .57 & very high \\
\hline 2. The communicative activities are varied, enjoyable, and fun. & 4.35 & .57 & very high \\
\hline
\end{tabular}




\begin{tabular}{|l|c|c|c|}
\hline $\begin{array}{l}\text { 3. The content of communicative activities and the activities themselves are } \\
\text { suitable for your proficiency level. }\end{array}$ & 4.02 & .91 & very high \\
\hline 4. The procedure of using communicative activities isclear. & 4.17 & .63 & very high \\
\hline 5. The topics and the content of communicative activities suit your needs. & 4.17 & .74 & very high \\
\hline $\begin{array}{l}\text { 6. The pictures provided in the communicative activities help you } \\
\text { understand the activities. }\end{array}$ & 4.15 & .86 & very high \\
\hline 7. The communicative activities are challenging. & 3.42 & 1.03 & very high \\
\hline 8. You understand the purpose of communicative activities clearly. & 4.32 & .65 & very high \\
\hline 9. The communicative activities motivate you to speak English. & 4.47 & .64 & very high \\
\hline 10. The communicative activities are appropriate forusing in English class. & 4.45 & .63 & very high \\
\hline \multicolumn{1}{|c|}{ Total } & 4.18 & .72 & very high \\
\hline
\end{tabular}

As seen in Table 6, we can see that the students' overall mean scores toward using communicative activities in speaking classes are very high $(\mathrm{M}=4.18)$. According to the results, we can see students' positive attitudes toward these activities. The highest positive attitude was toward item 9 $(\mathrm{M}=4.47)$. As students responded, these activities were effective for motivating them to speak. Item $10(\mathrm{M}=4.45)$ was the students' second highest positive attitude. The students confirmed that these activities were appropriate for using in the speaking classroom. However, the least positive reported attitude item by learners was item $7(\mathrm{M}=3.42)$. A few of them responded that communicative activities were challenging.

\section{Discussion and Conclusion}

Reviewing the result of this study, we can see the positive effect of communicative activities on the improvement of the second-year EFL students' speaking performance. At the end of the study, students' perceptions and attitudes were positive toward these activities. This study revealed that the issues related to teaching speaking are very useful and important to offer implications for policymakers, teacher educators, and teachers. The results of Nanthaboot (2012) and Phuphanpet's (2004) studies are in line with the results of the current study because these activities helped the students to improve their pronunciation, have fun in the class, improve their speaking skills, have greater confidence to speak and more chances to practice in the class and be able to speak fluently and correctly. Due to these reasons, the students expressed their satisfaction with communicative activities. The purpose of all activities was to motivate the students to do the activities for achievement in English speaking. Through doing communicative activities students learned language subconsciously. For instance, in doing the information gap activity, like communication in real life, the students concentrated on communicating in English using sentences and focusing on the meaning. After finishing the activities, their speaking ability gradually was improved.

\section{The Difference between the Students' Speaking Scores on the Pre-test and Post-test}

After learning through communicative activities, students' speaking ability was significantly different $(\operatorname{sig}=0.00, p<0.05)$. The researcher calculated the average mean score of three speaking pre-test and post-test scores presented by three raters that assessed students' speaking ability. The average mean score of students' post-test $(\mathrm{M}=84)$ was higher than the average score of the students' pre-test $(\mathrm{M}=74.58)$. Through conducting Wilcoxon signed-rank test, a significant difference was found between the pretest and post-test scores. Three raters separately rated students' speaking ability on pre-and posttest. To find a significant difference between two tests in each rater's assessment, the researcher used Wilcoxon signed-rank test for each rater's assessment separately. After analyzing the results of the Wilcoxon test for three raters' assessments, a significant difference was found in three raters' assessments concerning two tests. According to the results, it was seen that communicative activities were effective in improving students' speaking ability. They encouraged students to speak, provided 
opportunities for students to practice different types of activities, promoted them to learn language subconsciously, improved students' self-confidence, and lastly, they were appropriate to students' needs. These results are in line with Nanthaboot's (2012) study. Similar to the current study, three raters assessed the students' pre-and post-test scores, and inter-rater reliability was found among three raters' assessment of speaking test. In two studies, the participants' mean scores on the speaking posttest were higher than their speaking pre-test scores. These common results support the development of students' speaking ability after participating in the CLT classroom and practicing the target language through communicative activities.

\section{Students' Perceptions toward Using Communicative Activities}

The result with an overall mean of $(\mathrm{M}=4.31)$ revealed students' positive perceptions about using communicative activities in the CLT classroom. Due to learning through communicative activities, the students' views were changed about these activities because they are very useful and helpful in improving students' speaking ability, selfconfidence, participation in the classroom, and interaction with classmates. These results are in line with Park's (2005) study because students were free, confident to speak, and participated in the class actively. Participants believed that these activities encouraged them to participate in the classroom at the highest level. Therefore, it can be concluded that doing activities are the main factors to lead the student to create a relaxing atmosphere and unity. "Communicative activities are essential and should be presented in a situation or context and have a communicative purpose which must be engaging and meaningful" (Tekliuk, 2020, p. 218). In sum, the various, enjoyable communicative activities such as interesting topics, relaxing classroom atmosphere, and positive interaction were important factors to affect students' perceptions.

\section{Students' Attitudes toward Using Communicative Activities}

Reviewing the results of the students' attitude questionnaire, we can see the students' positive attitudes at a very high level $(\mathrm{M}=4.18)$ toward the activities. Gardner (1985) stated that a positive attitude and greater motivation are very effective factors to improve students' language proficiency. These activities were useful in gaining the students' satisfaction in all aspects. The majority of students expressed that these activities were fun, interesting, and motivating. All topics and the designing of the activities were appropriate to the students' proficiency levels. In addition, most of the students confirmed that these activities increased their willingness to speak English. The findings of this study take support from the studies (Kethongkum, 2005; Troudi \& Choy, 2006; Wongsuriya, 2003), due to finding development in students' confidence in speaking skills.Concluding the findings of these studies, it can be saidthat learning through communicative activities enabled students to communicate purposefully and their attitudes were changed positively toward using these activities in the classroom.

\section{Implications}

There is a gap between classroom practice and curriculum design. Despite developing learners' communicative skills, the focus of English classroom practices is on practicing the structural aspects of language. The main concern of policymakers should be filling the gap between policy and practice. In addition to this, they should be aware of classroom problems.

To improve speaking skills, students should practice spoken language. For having effective speaking classes, engaging students in classroom activities is necessary. Teachers should not neglect to listen to students' voices in classrooms. Appropriate methods should be selected for providing effective speaking classes.

Group work activities can provide more opportunities to practice spoken language. Teachers and teacher educators should consider the benefits of group work, especially small groups. The structure of activities can affect the usefulness of speaking activities.

Positive aspects of speaking classes will be useful for Pre-service teachers. Therefore, teacher-training programs should consider carefully students' opinions in designing a language-learning program. 
Implementing this type of speaking class in ELT departments in Turkey can be useful for proposed English teachers to increase their awareness of the importance of student negotiation-based classrooms.

In-service teachers should develop their awareness of action research. Designing a flexible curriculum can provide opportunities for teachers to listen to their students' voices and prepare new materials in their lesson plans. Teachers should not use more controlled speaking activities in course books.

To do activities, the procedures should be clear. Before letting the students do activities, the teacher should explain the procedure. When the teachers want to give the instructions, they should explain the way of doing the activities and then check the students' progress during feedback time. When teachers want to give instructions, attracting students' attention and using simple language by teachers is essential (Gower et al., 2005).

The practice is helpful for perfect learning every time. Therefore, EFL teachers should maximize the learners' practicing speaking. Students should spend much time practicing speaking. To do this, they can work in pairs and small groups to practice speaking as an effective way that creates interaction among the students in the CLT classroom.

\section{References}

Amin, Ahmad. "Attitude Towards Language in Sociolinguistics Settings: A Brief Overview." Journal of Research and Innovation in Language, vol. 2, no. 1, 2020, pp. 27-30.

Anastasi, Anne, and Susana Urbina. Psychological Testing. Prentice Hall, 1997.

Alagözlü, Nuray. "English as a Foreign Language Cul-De-Sac in Turkey." Procedia - Social and Behavioral Sciences, vol. 47, 2012.

Brignall, Mary. The Perception Process. WiseOnline, 2001.

Brown, H. Douglas. Principles of Language Learning and Teaching. Pearson Education, 2007.

Burns, Anne. Doing Action Research in English Language Teaching: A Guide for Practitioners. Routledge, 2010.

Farooq, Muhammad. "Creating a Communicative Language Teaching Environment for
Improving Students' Communicative Competence at EFL/EAP University Level." International Education Studies, vol. 8, no. 4, 2015, pp. 179-191.

Gardner, Robert. Social Psychology and Second Language Learning: The Role of Attitudes and Motivation. Edward Arnold, 1985.

Goh, Christine, and Vahid Aryadoust. "Investigating the Construct Validity of MELAB Listening Test through the Rasch Analysis and Correlated Uniqueness 103 Modelling." Spain Fellowship Working Papers in Second of Foreign Language Assessment, vol. 8, 2010, pp. 31-68.

Gower, R., et al. Teaching Practice: A Handbook for the Teacher in Training. Macmillan, 2005.

Işık, Ali. "Language Education and ELT Materials in Turkey from the Path Dependence Perspective." Journal of Hacettepe University Faculty of Education, vol. 40, no. 40, 2011, pp. 256-266.

Kemmis, Stephen and Robin McTaggart. The Action Research Planners. Deakin University Press, 1990.

Kethongkum, W. The Effect of Using English Supplementary Materials on Developing Listening and Speaking Competence of the Third Year Vocational Level Students in Tourism and Hotel Section at Premruetai Administration Technology School. Srinakharinwirot University, 2005.

Kunandar. Langkah Mudah Penelitian Tindakan Kelas Sebagai Pengembangan Profesi Guru. Raya Grafindo Persada, 2010.

Lamie, J. Evaluating Change in English Language Teaching. Macmillan, 2005.

Nanthaboot, Pranee. Using Communicative Activities to Develop English Speaking Ability of Mathayomsuksa Three Students. Srinakharinwirot University, 2012.

Oskamp, Stuart. Attitude and Opinions. PrenticeHall, 1977.

Park, Punahm. "Classroom Activities in an EFL Context: A Case Study of NNS \& NS Teacher." The Linguistic Association of Korea Journal, vol. 13, no. 22, 2005, pp. 69-95.

Phisutthangkoon, Kittiya. The Use of Communicative 
Activities to Develop English Speaking Ability of First Year Diploma Vocational Students. M.A., Srinakharinwirot University, Bangkok, Thailand, 2012.

Phuphanpet, U. The Effect of Using Oral Activities to Develop English Speaking Ability of the First Certificate Vocational Students. M.A., Srinakharinwirot University, Bangkok, Thailand, 2004.

Tekliuk, Hanna. "Communicative Language Teaching." Current Issues of the Humanities, vol. 4, no. 30, 2020, pp. 215-219.

Troudi, Salah and S. Chee Choy. "An Investigation into the Change in Perception of and Attitude Toward Learning in Malaysian College." International Journal of Teaching and Learning in Higher Education, vol. 18, no. 2,
2006, pp. 120-130.

English Language Curriculum For Primary Education. Turkish Education Board, MEB, 2006.

Uztosun, Mehmet Sercan. "An Interpretive Study into Elementary School English Teachers' Beliefs and Practices in Turkey." Turkish Online Journal of Qualitative Inquiry, vol. 4, no. 1, 2013a, pp. 20-33.

Wongsuriya, P. The Development of English Speaking and Listening Competence through Real Life Situation. Srinakharinwirot University, 2003.

Wulandari, Dwi, et al. "Teachers' Perception on Classroom Action Research." KnE Social Sciences, 2019, pp. 313-320.

\section{Author Details}

Ali Rezalou, Atatürk University, Turkey,Email ID: dostayanar@gmail.com.

Oktay Yağiz, Atatürk University,Turkey,Email ID: yoktay@atauni.edu.tr 